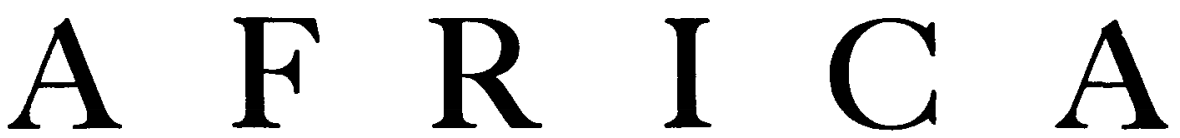

JOURNAL OF THE INTERNATIONAL INSTITUTE OF AFR I A N L A NGUAESAND CULTURES

\title{
TRIBUTES TO THE MEMORY OF LORD LUGARD
}

\section{LORD LUGARD'S INTERNATIONAL INFLUENCE}

By LORD HAILEY

TT has always been to me a matter of regret that I did not know Lord Lugard at an 1 earlier stage in his great career. My acquaintance with him dated indeed only from 1935, when I first began work on behalf of 'African Survey'. I need not say that I then received from him that generous assistance which he was always ready to give to those who were interesting themselves in a field of knowledge in which he had such an unrivalled mastery. Nor need I say that he was equally generous in the counsel and guidance he gave me when I subsequently succeeded him as member of the Permanent Mandates Commission at Geneva. At the first meeting of the Commission which I attended, his former colleagues spoke of him in terms which deeply impressed me. It was obvious that they had a most sincere appreciation of those personal qualities which had won for him so much respect among all students of Colonial affairs and so genuine an affection from a wide circle of friends in this country. But there was more; they had clearly recognized that his name had added distinction and prestige to the position which the Commission occupied in the international world.

This is no place to canvass the merits of the work of the Commission. There can be no question of the sincerity and purpose which distinguished its members. But, as a body, it had certain characteristics which will be readily acknowledged by those who were brought into close contact with it. Its personnel necessarily reflected a variety of political philosophies and, in consequence, a certain diversity of approach in dealing with the methods and objectives of Colonial administration. There was always some tendency, therefore, to concentrate attention on questions involving the interpretation to be placed on the prescriptions of the Mandate, rather than on the effect which administrative action might have on the welfare of the native population. It contributed also to this tendency, that there were some members of the Commission who, earnest as they were in their study of the documents presented to it, had not that background of experience which would enable them to assess their

'Africa', the Journal of the International Institute of African Languages and Cultures, is published by the Institute, but except where otherwise stated the writers of the articles are alone responsible for the opinions expressed. 
bearing on matters which were actually most vital to the native population. Conscientious and unsparing though he was in the discharge of his service to the Commission, Lugard must often have found some of its more discursive and dialectical discussions a strain on his sense of realities, though his innate courtesy forbade him to show it. It was his constant mission to bring debate back to the points which his own informed knowledge, and his instinctive appreciation of the concrete effects of policy, distinguished as those on which the intervention of the Commission could be most effective. Here his influence was always felt, and it was here that he could, and did, make a contribution of signal value to the work of the Commission. And it counted for much in the achievement of this influence, that he was no less incisive in his examination of British policy than in that of other Mandatory Powers.

In later years his home at Abinger became almost a place of pilgrimage to those who were interested in the study of the problems of Africa or in Colonial affairs. His visitors were of many types, but they were sure of a sympathetic and understanding reception if their objec $t$ was serious, for he was always reluctant to assist those who wished to draw on his experiences merely for purposes of publicity. He especially welcomed foreign visitors, for while he never wavered in his conviction that Britain could not share with an international agency its responsibility for the administration of its Colonies, he had a strong faith in the value of extending the international study of colonial affairs and of co-operation in the solution of their problems.

It was largely this sentiment which influenced him in giving so many years of devoted care to the affairs of the International African Institute. In his view, the development of Africa could not be achieved by a rapid Europeanization, but under conditions which would allow the fullest scope to the innate characteristics of the African. If we were to aid him in this process, a full knowledge of his traditional institutions, his culture, and his language was essential; but this study must proceed on the widest basis, and it demanded the association of foreign no less than of British scholars.

Always indefatigable in the discharge of any responsibility he had undertaken, Lord Lugard did not allow either advancing age nor his many other preoccupations to impair the interest which he gave to the Institute. Fate has decreed that he should leave its guidance to others at a moment when the greatly extended importance accorded to the problems of Africa, and the more liberal provision made for their study, permit us to hope that it will have a wider range of activity and a larger scope for service to Africa. More than ever, therefore, shall we feel the loss of his wise counsel, and miss the leadership of one whose name was able to secure for the Institute an exceptional authority in the field of social and cultural research to which its energies are devoted.

\section{LORD LUGARD AS CHAIRMAN OF THE INSTITUTE}

BY DR. J. H. OLDHAM

THE Institute of African Languages and Cultures was launched at a meeting held 1 in London in June 1926. It was attended by twenty experts and others interested in African affairs from eleven countries. The chair was taken by Lord Lugard-then 
styled Sir Frederick-and he was elected Chairman of the Executive Council, an office which he continued to hold by the unanimous desire of the Council for nearly nineteen years. He was in no sense an honorary or nominal Chairman. As he told the Bureau of the Institute when announcing his resignation on grounds of failing health, a little more than a fortnight before his death, the Institute had for all these years been one of the major preoccupations of his life. There was not a paper issued in connexion with its work which he did not read and carefully annotate, and he studied with care all the voluminous reports submitted by its research Fellows.

He was the outstanding figure connected with African affairs, and the prestige of his name, not only in Britain but also in other countries with African dependencies, was such that his identification with the Institute immediately secured for it a status that it would otherwise have taken longer to attain. It greatly facilitated approach to the Colonial governments and helped to secure the ready co-operation of leading scholars in many countries. Those whose interest was won in the first instance by his name and reputation were captivated as soon as they got to know him by his personal charm and unfailing courtesy, by the breadth of his knowledge and the ripeness of his wisdom. All the members of the Executive Council, whatever their nationality, became greatly attached to him.

In his determination to make the Institute a genuinely international undertaking he was greatly helped by the remarkable linguistic gifts of the late Sir Hanns Vischer, The latter had been admitted into the British Colonial service by Lord Lugard, and between the two men there was a deep and long-standing attachment, so that they worked together with the greatest ease and with mutual confidence. Equally close was the bond between Lord Lugard and Professor Westermann, in whose hands lay the main direction of the Institute's scientific work. Widely diverse as were their backgrounds, each instinctively recognized in the other a profound love for Africa, and this formed a basis for deep mutual understanding.

Lord Lugard had from the beginning a remarkable vision of the possibilities of a body like the African Institute. He was equally concerned about two things: first, that the scientific character of the Institute should be maintained; and, secondly, that its scientific work should be directed to serving the practical needs of Africa. He recurred to this theme in the last letter I received from him, written less than a fortnight before his death. 'Subjects for research', he wrote in regard to the Institute's programme, 'were by no means confined to anthropology. I well remember that when we first discussed together the possibility of forming an international Institute, I said that I thought there were already too many academic societies and that what was now required was an international body which could do something practical for Africa. I think we may say that something practical was done, e.g. by stimulating interest in African sociological and linguistic problems through fellowships open to all nations, by training several Fellows who are now in Government employ, by Westermann's practical advice to the Gold Coast and the Sudan on the selection of key languages for study, by Westermann's orthography, by prizes for essays or stories by Africans in their own languages, and by encouraging research into African nutrition. These points occur to me at the moment. Had we been able to continue the Fellowships, there are other practical problems which I should have liked to suggest for research.' 
It was because he saw in the African Institute an opportunity of continuing to serve the Africa which he loved that he gave it unstintedly a substantial part of his later years.

\section{LORD LUGARD, THE MAN}

\section{By THE EDITOR}

THE story of Lord Lugard's effective entry upon the African scene takes us into the region of knight-errantry. In 1887 he was in his thirtieth year, already a soldier of distinction, one of the first to be awarded the D.S.O. Finding himself at Gibraltar with health shattered after many years of continuous service in the Eastincluding campaigns in Afghanistan, the Sudan, and Burma-he was at his request placed on temporary half-pay. What should he do now? 'What I felt I needed', he wrote, ' was active hard work-rather than rest.' So with an old rifle, earned by shooting a man-eating tiger with a reward on its head, and with fifty sovereigns in his belt, he boarded the first passing ship and sailed-' I knew not whither'. His hope was that he ' might embark in some useful undertaking in Africa, if possible in the suppression of the slave-trade'. As he travelled along the East coast and heard of the ravages of that traffic, his keen mind penetrated to the kernel of the problem. 'We must go to the root of the evil and crush the trade'-in the interior. The opportunity came when at Mozambique Consul O'Neill told him how a body of slavetraders had gratuitously attacked a small British trading station at the northern end of Lake Nyasa and suggested that he should go to the relief of the sorely beset pioneers. It was characteristic of him that he would not accept the suggestion 'unless the fighting was fully justified' in his view. Satisfied on this point he journeyed to Blantyre and there accepted leadership of a small expedition of eighteen men, including Alfred Sharpe and Dr. Kerr Cross, a medical missionary. He had the Consul's sanction for going but, says he, 'I would have gone even without such approval', and at the risk of his commission, so serious did the crisis seem to him. In the subsequent fighting Captain Lugard was seriously wounded and owed his life to the care and skill of Dr. Cross. He refused to leave his post until practically forced by his heroic comrades. While convalescing at Blantyre he drew up a scheme for the suppression of the slave-trade in Nyasaland. Then he went back to the little war. When he finally returned to England he was officially reprimanded for outstaying his leave but was most cordially congratulated by the Commander-in-chief on his gallantry.

This experience in Nyasaland determined the direction of Lord Lugard's future career. Henceforth, following in his own way the course laid down by Livingstone and Kirk, he was devoted to Africa and the Africans. It is not for us to pursue his brilliant progress further-through Uganda and Nigeria. We would only draw attention to the very remarkable book, The Rise of our East African Empire, which he published in 1893 - remarkable not only for the incidents it relates but much more for the writer's prescience and sane view of the situation. Here, before he saw the Niger, we already have a forecast of what was to be known as 'Indirect Rule'. 'With regard to internal control in Uganda,' he wrote, ' in my opinion the object 
to be aimed at in the administration of this country is to rule through its own executive government.'

Lord Lugard's service in Africa culminated in the Governor-Generalship of Nigeria, the greatest of Britain's colonial dependencies; and he retired from this office and from the Colonial Service in 1919. Thenceforth his beautiful home in Surrey was the centre of an astonishing activity. For many years he was engaged in preparing a new edition of his famous book The Dual Mandate, first published in 1922. Every new fact, every fresh argument on colonial policy, was noted for consideration; chapters were re-written and later written again. The material grew so bulky that finally, as old age crept upon him, this ambitious project had to be laid aside. Meanwhile from 1923 to 1936 he was a member of the Permanent Mandates Commission. His home became the rendezvous for all who sought counsel on African affairs. During all these years of 'retirement' he was as busy as any man in London. He worked habitually at his desk until the early hours of the morning.

A man of action, fearless and resolute; a thinker, exploring the philosophy of colonial administration; a humanitarian, fighting the evils of slavery in all its many forms, whether in Nyasaland, Uganda, Nigeria, or at Geneva - the Institute may well be proud of having had Lord Lugard as its Head.

It was always most difficult to induce him to talk of his experiences-on his own exploits he was almost inflexibly reticent. A magnificent elephant tusk hung in his room: 'Yes', he said in answer to a question, 'I shot him near Lake Albert; I will tell you about it some time' - but he never did. As we walked through the House of Commons one day (after he had entertained members of the Council on the Terrace) he grew rather more communicative. Pointing to a secluded seat in the Chamber, he told how he sat there during a debate on the question whether Britain should evacuate or retain Uganda, and passed notes to speakers, controverting arguments brought forward by the opposition; he told with glee how officials of the House came to reprimand him for his disorderly conduct and how, as soon as their backs were turned, he went on supplying verbal ammunition. One evening, while the Council was meeting in Paris, conversation turned on Henry M, Stanley and Lord Lugard told in indignant tones of the evidence he had found of Stanley's brutalities, and how when they chanced to meet in a London club he had refused to shake Stanley's hand: it was the only time, in our experience, that he spoke harshly of another man. One tried to draw him out sometimes by asking whether a certain story about him were true. What of the story of appearing at a review in Nigeria with a huge splotch of ink on his white tunic? Yes, while dressing for a review of the horsemen of an Emir, he had the misfortune to spill a bottle of ink on his only white tunic; and there was nothing to do but wear it. When he rode on to the parade ground with this distinguishing mark between his shoulders, people took it for the insignia of a new rank bestowed upon him by the King of Britain, and they were much impressed.

The death of Lord Lugard marks the passing of a great era in African history. He was the last of the Paladins. The new generation faces new conditions and new problems. May it face them with the same high-hearted courage and resolution and strong moral purpose that characterized the great leader for whom the trumpets have now sounded on the other side. 